\title{
Chemopreventive and Antiproliferative Effect of Andrographis Paniculata Extract
}

\author{
Agrawal RC ${ }^{1 *}$, Agrawal $\mathrm{N}^{1}$, Mishra $\mathrm{D}^{1}$ \\ ${ }^{1}$ Department of Research, Priyamvada Birla Cancer Research Institute, J. R. \\ Birla Road, Satna-485005, Madhya Pradesh, India.
}

Correspondence: Agrawal RC. Email: rcagrawal60@yahoo.com.

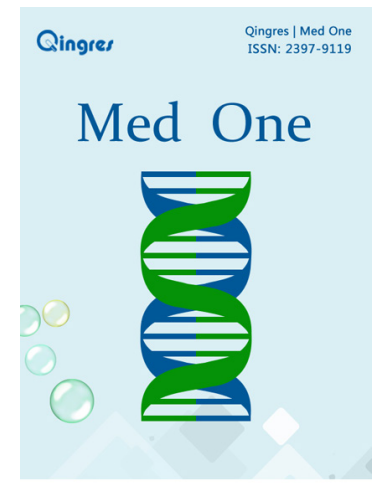

http://mo.qingres.com

\section{GOPEN ACCESS}

DOI: $10.20900 / \mathrm{mo} .20170011$

Received: March 10, 2017

Accepted: May 18, 2017

Published: June 25, 2017

Copyright: ๑2017 Cain et al. This is an open access article distributed under the terms of the Creative Commons Attribution License, which permits unrestricted use, distribution, and reproduction in any medium, provided the original author and source are credited.

\begin{abstract}
An Andrographis paniculata leaf and stem extract was studied in Hela cells lines by In Vitro methods and anti promoting effect by skin tumour model. The dose dependent cytotoxicity was observed in HeLa cell lines by stem and leaves extracts of Andrographis paniculata extract. The prevention of bone marrow micronucleus formation by Andrographis paniculata leaves and stem extract was also observed. The reductions in tumour numbers were observed. The glutathione level was increased in the liver of animals which received the treatment of Andrographis extract along with DMBA + Croton Oil. The revealing information about the anticancer, antiproliferative and antimutagenic effect of an Andrographis paniculata extract was observed.
\end{abstract}

Key words: Micronucleus; Bone marrow; Glutathione; Hela cells; Papilloma

\section{INTRODUCTION}

Andrographis paniculata is used in Asia from centuries in traditional medicine to treat gastrointestinal (GI) tract and respiratory infectious diseases. It has been reported that Andrographis has a broad range of pharmacological effects ${ }^{[1]}$. It has been suggested it's safe in controlled clinical trials report for treating upper respiratory tract infections. It also showed significant cardio protection by inducing antioxidant activity in myocardium ${ }^{[2]}$. Cytotoxic activity against cancer cell lines has been reported by Compounds of Andrographis paniculata ${ }^{[3]}$. Antimicrobial activity against eleven bacterial strains by ethanol extract of Andrographis paniculata have been reported ${ }^{[4]}$. Andrographolide have been reported to hypoglasmic activity in rats ${ }^{[5]}$. Antiulcer activity was reported in duodenal ulcer model in rats ${ }^{[6]}$. Hepatoprotective effect was reported on acetaminophen induced hepatotoxicity in albino rats ${ }^{[7]}$. An andrographolide was also reported to induce apoptosis in TD-47 human breast cancer cell line in a time and concentration-dependent manner by increase expression of $p 53$, bax, immuno histochemical parameters 
such as caspase- 3 and decrease expression of bcl-2 ${ }^{[8]}$. Andrographis paniculata, dry leaf powder was reported to spermatogenesis, cessation of degenerative changes in the seminiferous tubules ${ }^{[9]}$. The extract produced significant muscarinic activity, which accounts for its antivenom effects ${ }^{[10]}$. Many of the conditions commonly treated with Andrographis paniculata in traditional medical systems are important, which requires further investigations for benefit in cancer treatment.

\section{MATERIALS AND METHODS}

\subsection{Chemicals}

The MTT cell culture tested reagent, 2,2 Diphenyl1-picryl hydrazyl, 5,5 dithiobis (2 nitrobenzoic acid) were obtained from Hi media co., croton oil, 7,12 Dimethylbenz (a) anthracene (DMBA), purchased from Sigma Chemicals Co. (St. Louis, MO. USA). Other chemicals were obtained Ranbaxy and SRL laboratories, Mumbai and purchased from local firms and were of the highest purity.

\subsection{Animals}

The experiment was approved by Institutional animal ethic committee before conduction of the experiments. These Swiss albino mice were housed in polypropylene cages at temperatures of $24 \pm 30$.C. Mice were provided with standard mice feed and tap water ad libitum.

\subsection{Preparation of Andrographis paniculata leaves and stem extract}

Plant material (Andrographis paniculata) was collected and the specimen was authentified by the botanist of Deen dayal Research Institute, Chitrakoot (MP), and India. Leaves and stem were washed, air dried, powdered and extracted separately using $50 \%$ methanol in a separating funnel. Extract thus obtained were vacuum evaporated into powder. These extract was again dissolved in double distilled water (DDW) immediately prior topical application. We have already done pharmacological screening of the components of extract in different solvent system such as methanol, Ethanol, Benzene and chloroform which showedthe presence of carbohydrate, flavonoid, Glycoside, Steroid, Resin, Tanin, Alkaloid.

\subsection{Experimental design for Skin Carcinogenesis}

One day before the experiment commenced, the dorsal skin on the animal's back was shaved. Two stage protocol was used as described by Berenblum ${ }^{[11]}$ and standardized by Agrawal et al ${ }^{[12]}$. Animals were randomly allocated into 7 groups of comprising six mice each group. Single topical application of a carcinogen7, 12-dimethylbenz (a) anthracene (DMBA)and then followed by a promoter (croton oil) twice in a week were used to induce tumours. The detail protocol was described in our earlier published paper ${ }^{[17]}$. The treatment was provided topically to the shaved area. All animals groups were observed for gross and microscopic changes weekly All mice were weighed and examined for skin papillomas and results were recorded. The glutathione levels were measured by the method as described by Sedlak and Lindsay, $1968^{[19]}$.

\subsection{MTT Assay}

The extract of Stem and leaf of Andrographis paniculata on Hela cell line was studied. It was determined by MTT assay as described by Mosmann, $1983^{[16]}$. For MTT assay, the extract at the dose of $(0-1000 \mu \mathrm{g} / \mathrm{ml}$ and $5 \mu \mathrm{l} / 100 \mu \mathrm{g}$ of cell suspension) was kept for 24 hours. Hela cells were cultured and treated with different concentrations of extract. 2 hours prior to the termination of experiment, MTT was added to cell culture at 0.25 $\mathrm{mg} / \mathrm{ml}(5 \mu \mathrm{l}$ of $5 \mathrm{mg} / \mathrm{ml}$ in $100 \mu \mathrm{l}$ of cell suspension) concentration. At the end of the experiment, culture supernatant was removed and cell layer was dissolved in DMSO and further read in a plate reader at $550 \mathrm{~nm}$ and $660 \mathrm{~nm}$. graph 1 and 2 plotted between the relative percentage death of cells against different concentration of Andrographis extract after 24 hour.

\subsection{Micronucleus Assay}

It was done by the method as described by Schmid $(1975)^{[13]}$ and Aron et $a^{[14]}$ and standardized by Agrawal et al ${ }^{[15]}$. For the micronucleus assay, the extract at the volume of $0.2 \mathrm{ml}$ at different doses level such as 500, 1000 and $1500 \mathrm{mg} /$ $\mathrm{kg}$ body weight was injected 24 hours before the treatment of Cyclophosphamide to three animals. The positive control group received single ip. dose of Cyclophosphamide The cell were stained with May-Grunewald and Giemsa, and observed under microscope at 10X100X magnification. The detail protocol a described in our earlier paper Agrawal et $a^{[15]}$.

\section{RESULTS}

The result showed that the animals of Group-V (control) produced skin papillomas, in all animals 
(100\%) which were observed from 5 th week onwards. The significant tumour prevention was observed in the Andrographis paniculata extract treated experimental groups $(25 \%$ and $0 \%$ in group VI \& VII) compared to the carcinogen control. Cumulative number of papillomas was also reduced in the Andrographis paniculata leaves and stem extract treated along with DMBA + Croton Oil groups
(5 and 0 in group VI \& VII). DMBA + Croton Oil treated showed Tumor burdens and tumor yields (3.5) where as it was decreased (0.5) in androgrraphis extract treatedgroup (Table 1).The acute toxicity of Andrographis methanolic extract has been studied. It was observed that animals showed no toxicity up to the dose of $3000 \mathrm{mg} / \mathrm{kg}$ body weight in Swiss albino mice.

Table 1. Showing No. of Papilloma in the animals treated with Andrographis paniculata extract

\begin{tabular}{|c|c|c|c|c|c|c|}
\hline Group & Treatment & Dose & $\begin{array}{l}\text { Time of } 1 \text { st } \\
\text { appearance of } \\
\text { Papilloma }\end{array}$ & $\begin{array}{l}\text { Cumulative No. } \\
\text { of Papilloma }\end{array}$ & Tumour yield & $\begin{array}{l}\text { Tumour } \\
\text { incidence }\end{array}$ \\
\hline I & Vehicle alone & $100 \mu \mathrm{l} /$ animal & - & - & - & - \\
\hline II & DMBA alone & $100 \mu \mathrm{g} / \mathrm{animal}$ & - & - & - & - \\
\hline III & $\begin{array}{l}\text { Croton Oil } \\
\text { alone }\end{array}$ & $1 \%$ per animal & - & - & - & - \\
\hline IV & $\begin{array}{l}\text { Andrographis } \\
\text { Extract alone }\end{array}$ & $500 \mathrm{mg} /$ animal & - & - & - & - \\
\hline V & $\begin{array}{l}\text { DMBA + CO } \\
\text { (Control) }\end{array}$ & $\begin{array}{l}100 \mu g+1 \% \text { per } \\
\text { animal }\end{array}$ & 58th Day & 21 & $\begin{array}{l}21 / 6^{* *} \\
(3.5)\end{array}$ & $6 / 6(100 \%)$ \\
\hline VI & $\begin{array}{l}\text { DMBA+ } \\
\text { Andrographis } \\
\text { ( Leaves) } \\
\text { Extract.+ CO }\end{array}$ & $\begin{array}{l}100 \mu \mathrm{g}+1 \%+ \\
500 \mathrm{mg} / \text { animal }\end{array}$ & - & 0 & $0 / 3$ & $0 / 6(0 \%)$ \\
\hline VII & $\begin{array}{l}\text { DMBA+ } \\
\text { Andrographis ( } \\
\text { Stem )Extract.+ } \\
\text { CO }\end{array}$ & $\begin{array}{l}100 \mu g+1 \%+ \\
500 \mathrm{mg} / \text { animal }\end{array}$ & 61th Day & 5 & $5 / 4$ & $1 / 4^{*}(25)$ \\
\hline
\end{tabular}

*Denotes statistically significant as compared to control in Students 't' test at $p<0.05$. ${ }^{* *}$ denotes total no. of Papilloma tumour/Total no. of animals

The induction of glutathione was also measured in the groups which were studied in papillioma models. The induction of glutathione level was significant in liver as compared to carcinogen control group. The result suggest significant increase levels of Glutathione (GSH) in Liver of Papilloma bearing Swiss albino mice receiving treatment of $A$. Paniculata extract whereas in blood tissue it was almost similar to carcinogen control group and lower to untreated control group. 
Table 2. Showing the level of Glutathione (GSH) in Blood and Liver

\begin{tabular}{|c|c|c|c|c|}
\hline \multirow{2}{*}{ S.No } & \multirow{2}{*}{ Groups } & \multirow{2}{*}{ Treatment Group } & \multicolumn{2}{|c|}{ Glutathione level } \\
\hline & & & Blood $(\mu \mathrm{g} / \mathrm{ml})$ & Liver $(\mu \mathrm{g} / \mathrm{ml})$ \\
\hline 1 & I & Normal mice & $4.58 \pm 0.65$ & $53.8 \pm 8.34$ \\
\hline 2 & II & Carcinogen control (DMBA+CO) & $2.7 \pm 0.06$ & $14.95 \pm 9.75$ \\
\hline 3 & III & DMBA+A.pan +CO( Leaves) & $2.12 \pm 0.42$ & $46.33 \pm 28.36^{*}$ \\
\hline 4 & IV & DMBA+A.pan +CO( Stem) & $3.07 \pm 2.07$ & $30.54 \pm 14.62^{*}$ \\
\hline
\end{tabular}

*Denotes significant as compared to carcinogen control in students't' test. at $p<0.05$.

The cytotoxicity of the plant was studied using HeLa cell lines in Vitro models. It shows that whole plant extract of Andrographis paniculata had cytotoxic activity. Fig. 1 and 2 showed the relative percentage death of cells against different concentrationof Andrographis extract after 24 hour.

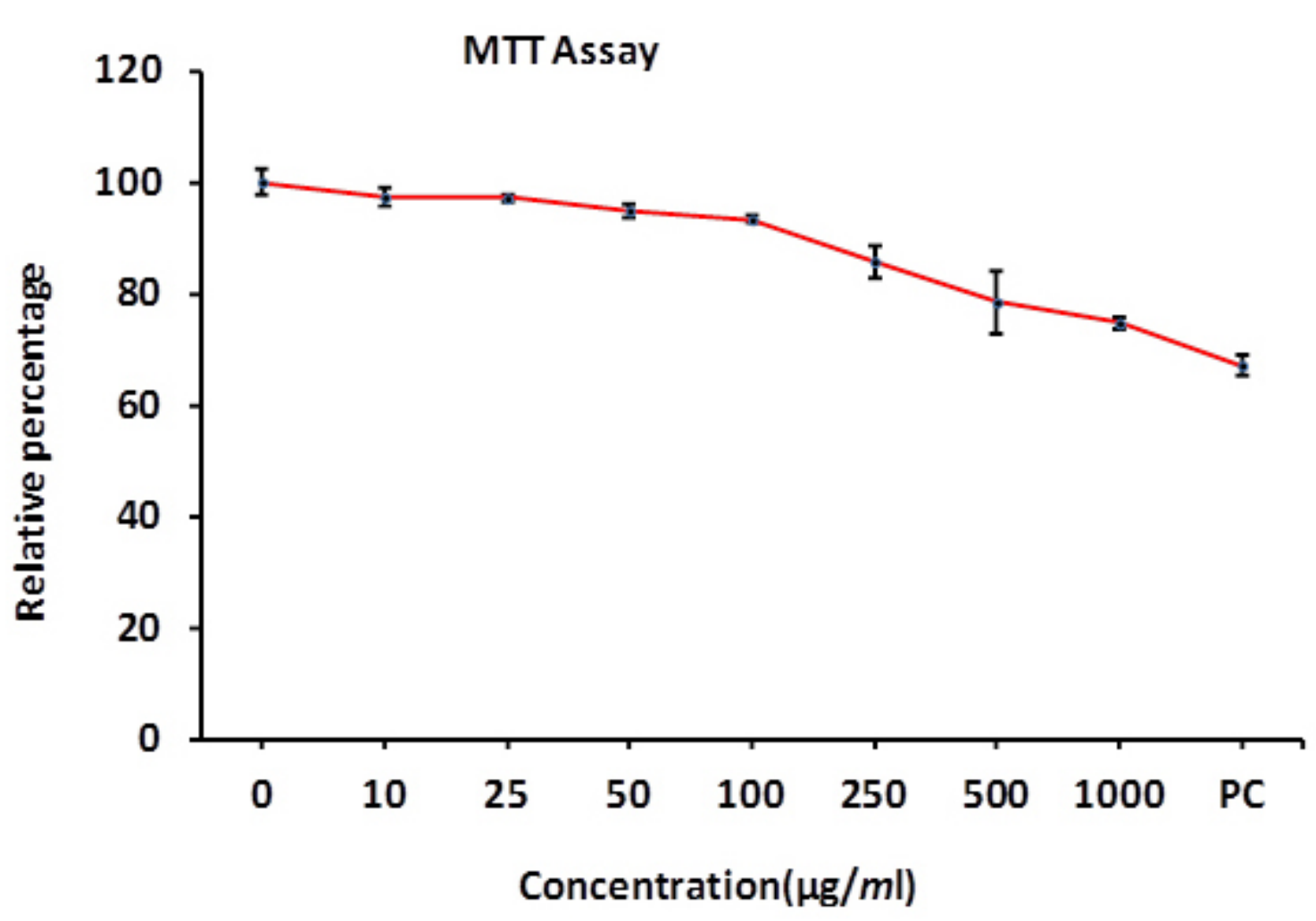

Fig. 1 Effect of leaf extract of Andrographis Paniculata on HeLa cell line for 24h by MTT Assay. 


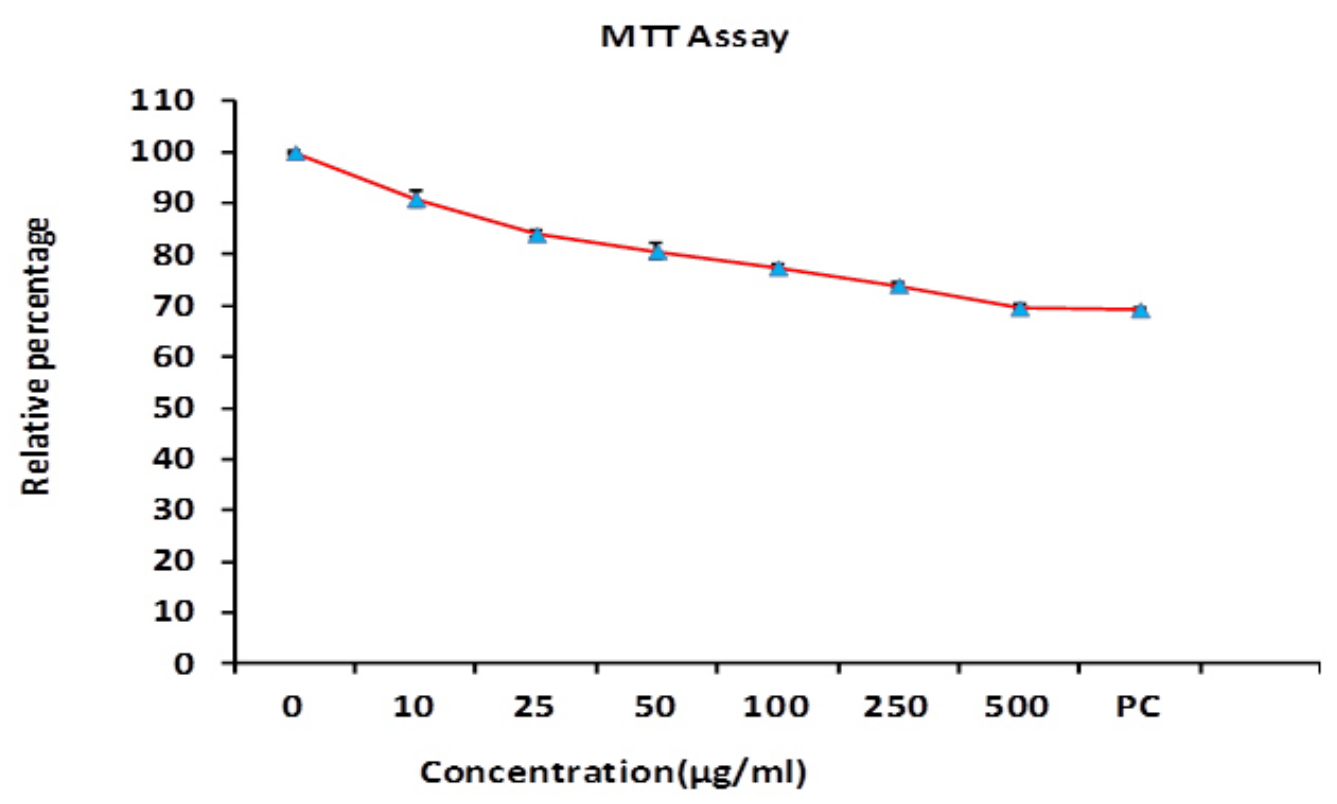

Fig. 2 Effect of whole plant extract of Andrographis Paniculata on HeLa cell line for 24h by MTT Assay.

In the micronucleus assay Cyclophosphamide (CP) has been used as a clastogen and anticlastogenic effect of A.panniculata (AP) has been observed in bone marrow cells of mice. The Andrographis extract showed a significant reduction in number of micronuclei as compared the CP alone. The result of Micronucleus assay showed that single application of $A$. paniculata hydro methanolic leaves extract (i.p.) at the dose levels showed the significant reduction of micronucleus formation in PCE cell of bone marrow. However the micronucleus protection was not significantin stem extract of Andrographis extract treated group. The PCE/NCE ratio was comparable in all treated group as compared to $\mathrm{CP}$ which showed no toxicity of the extract in bone marrow cells of mice. (Table 3 \& 4, Fig. 3)

Table 3. Effect of A. paniculata leaves extract on Micronucleus (MN) formation induced by Cyclophosphamide (CP) in bone marrow cells of Swiss albino mice.

\begin{tabular}{|c|c|c|c|c|c|}
\hline S No. & Groups & $\begin{array}{l}\text { Treatment Doses } \\
\text { (mg/kg body wt) }\end{array}$ & MNPCE \pm SEM & $\begin{array}{l}\text { PCE/NCE } \\
\text { Ratio } \pm \text { SEM }\end{array}$ & $\begin{array}{l}\text { \% reduction in the } \\
\text { frequency of } \mathrm{CP} \\
\text { induced DNA damage }\end{array}$ \\
\hline 1. & I & $\begin{array}{l}\text { Cyclophosphamide Alone } \\
\text { (50mg/kg b.wt) }\end{array}$ & $3.5 \pm 1.1$ & $0.99 \pm 0.08$ & - \\
\hline 2. & III & $\begin{array}{l}\text { A.paniculata }(500 \mathrm{mg} / \mathrm{kg} \\
\text { b.wt)+ CP (50mg/kg b.wt) }\end{array}$ & $2.2 \pm 1.3^{*}$ & $0.61 \pm 0.14$ & $37.2 \%$ \\
\hline 3. & IV & $\begin{array}{l}\text { A.paniculata }(1000 \mathrm{mg} / \mathrm{kg} \\
\text { b.wt)+ CP (50mg/kg b.wt) }\end{array}$ & $1.6 \pm 0.8^{*}$ & $1.03 \pm 0.12^{*}$ & $55.3 \%$ \\
\hline 4. & V & $\begin{array}{l}\text { A.paniculata (1500mg/kg } \\
\text { b.wt)+ CP (50mg/kg b.wt) }\end{array}$ & $0.5 \pm 0.3^{*}$ & $1 . .03 \pm 0.12^{*}$ & $85.8 \%$ \\
\hline 5. & II & $\begin{array}{l}\text { A.paniculata } \\
\text { alone(1500mg/kg b.wt) }\end{array}$ & $0.4 \pm 0.3$ & $0.03 \pm 0.12$ & - \\
\hline 6. & VI & Vehicle alone (DDW) & $0.16 \pm 0.16$ & $0.44 \pm 0.08$ & - \\
\hline
\end{tabular}

*Denotes statistically significant as compared to cyclophosphamide group at $p<0.05$. 
Table 4. Effect of A. paniculata stem extract on Micronucleus (MN) formation induced byCyclophosphamide (CP) in bone marrow cells of Swiss albino mice.

\begin{tabular}{|c|c|c|c|c|c|}
\hline S No. & Groups & $\begin{array}{l}\text { Treatment Doses } \\
\text { (mg/kg body wt) }\end{array}$ & MNPCE $\pm S E M$ & $\begin{array}{l}\text { PCE/NCE } \\
\text { Ratio } \pm \text { SEM }\end{array}$ & $\begin{array}{l}\% \text { reduction in the } \\
\text { frequency of } \mathrm{CP} \\
\text { induced DNA damage }\end{array}$ \\
\hline 1. & I & $\begin{array}{l}\text { Cyclophosphamide } \\
\text { Alone(50mg/kg b.wt) }\end{array}$ & $3.5 \pm 1.1$ & $0.99 \pm 0.08$ & - \\
\hline 2. & III & $\begin{array}{l}\text { A.paniculata( } 500 \mathrm{mg} / \mathrm{kg} \\
\text { b.wt)+CP }(50 \mathrm{mg} / \mathrm{kg} \text { b.wt })\end{array}$ & $2.5 \pm 1.22$ & $0.62 \pm 0.20$ & $28 \%$ \\
\hline 3. & IV & $\begin{array}{l}\text { A.paniculata }(1000 \mathrm{mg} / \mathrm{kg} \\
\text { b.wt)+CP }(50 \mathrm{mg} / \mathrm{kg} \text { b.wt) }\end{array}$ & $2.6 \pm 0.89$ & $0.587 \pm 0.12$ & $25 \%$ \\
\hline 4. & V & $\begin{array}{l}\text { A.paniculata }(1500 \mathrm{mg} / \mathrm{kg} \\
\text { b.wt)+CP }(50 \mathrm{mg} / \mathrm{kg} \mathrm{b.wt})\end{array}$ & $2.6 \pm 1.14$ & $0.68 \pm 0.12$ & $25 \%$ \\
\hline 5. & II & $\begin{array}{l}\text { A.paniculata } \\
\text { alone(1500mg/kg b.wt) }\end{array}$ & $0.82 \pm 0.66$ & $0.53 \pm 0.054$ & - \\
\hline 6. & VI & Vehicle alone (DDW) & $0.16 . \pm 0.16$ & $0.44 \pm 0.08$ & - \\
\hline
\end{tabular}

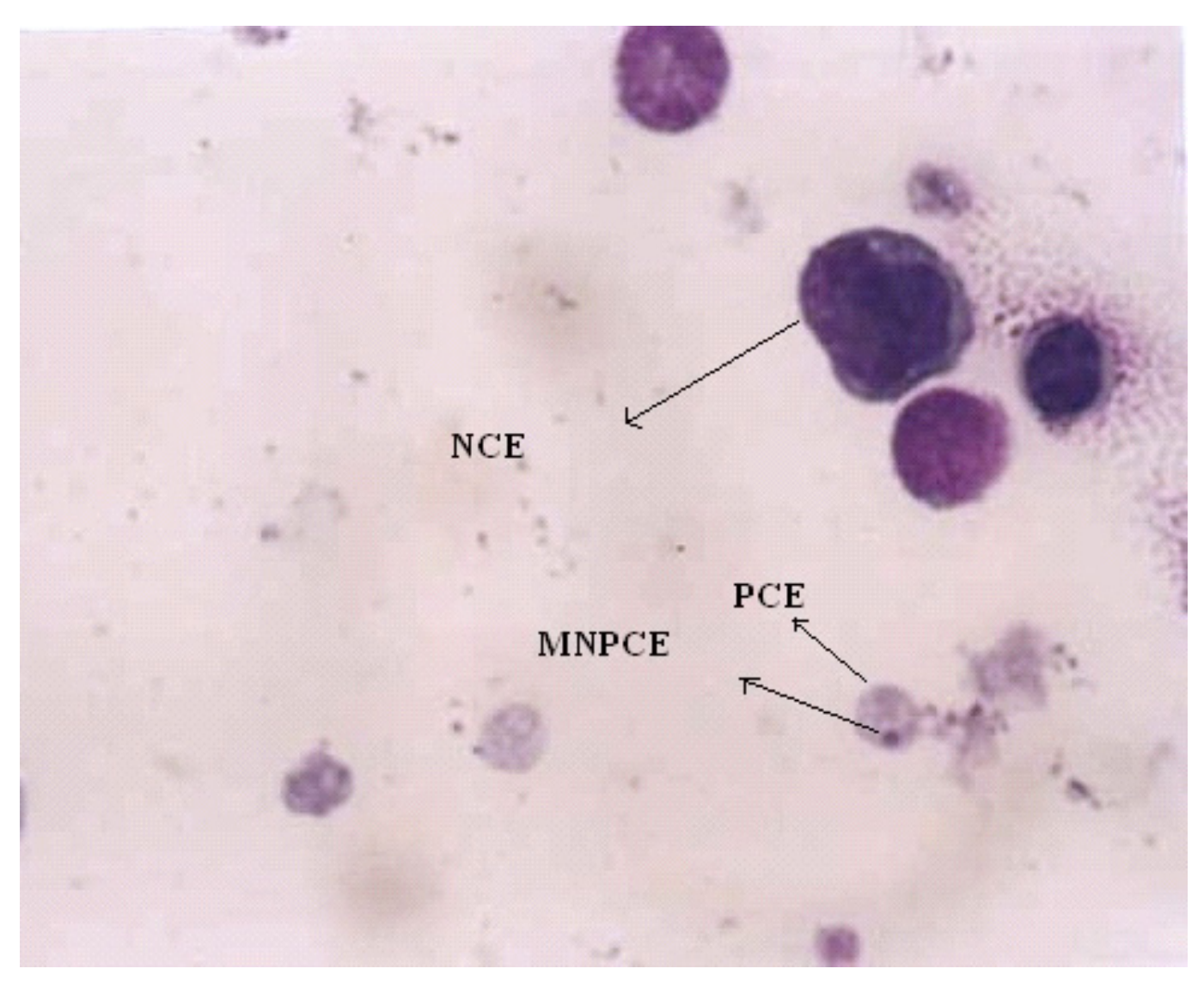

Fig. 3 Showing Micronucleus (MN) in polychromatic erythrocytes. 


\section{DISCUSSIONS AND CONCLUSION}

The current study demonstrates anticarcinogenic, antoproliferative and antimutagenic potential of Andrographis paniculata stem and leaves (AP) extract in skin papillomas, Hela cells lines and in bone marrow micronucleus assay. It demonstrates that a topical application of andrographis paniculata leaves and stem extract (500 mg/kg body weight) showed significant reduction in tumor incidence, in andrographis treated groups relative to the carcinogen treated control. In our previous study the anticarcinogenic activity of androgrphis paniculata leaves has been reported ${ }^{[17]}$. The methanolic extract of leaves of AP was more effective than stem extract in both Papilloma and micronucleus assay. The mechanism which shows induction of glutathione levels in liver tissues may be due to detoxification mechanism by liver of the animals. However the cytotoxicity anticarcinogenicity may be due to reactive oxygen species ${ }^{[18]}$. The present study suggests the anticarcinogenic and antimutagenic activity of Andrographis. paniculatawhich is an important drug in traditional medicine and may be useful in treatment of cancer patients.

\section{ACKNOWLEDGEMENTS}

The authors are thanking to the M.P. Council of Science and Technology, Bhopal for its financial assistance and Dr. S.K. Maheshwari, Medical Director of PBCRI, Satna for providing facility to conduct the above work.

\section{REFERENCES}

1. Sandberg F. Andrographidis herba Chuanxinlian: A review. Gothenburg, Sweden: Swedish Herbal Institute. Available from the American Botanical Council (USA). 1994.

2. Ojha SK, Bharti S, Joshi S, Kumari S, Arya DS. Protective effect of hydroalcoholic extract of Andrographis paniculata on ischaemiareperfusion induced myocardial injury in rats. Indian J Med Res. 2012; 135: 414-421.

3. Aditya VS, Kumar NL, Mokkapati A. Evaluation of in vitro cytotoxicity of Andrographis paniculata, Duranta serratifolia and Albizzia lebbeck whole plant extracts by MTT assay against MCF-7 and HT-29 cell lines. Cur Res Microbiol Biotechnol. 2014; 2(2): 351-353.
4. Mishra US, Mishra A, Kumari R. Murthy PN, Naik BS. Antibacterial activity of ethanol extract of Andrographis paniculata. J Pharm Sci. 2009; 71(4): 436-438.

5. Nugroho AE, Andrie M, Warditiani NK, Siswanto E, Pramono S, Lukitaningsin E. Antidiabetic and antihiperlipidemic effect of Andrographis paniculata (Burm. f.) Nees andandrographolide in high-fructose-fat-fed rats. Indian J Pharmacol. 2012; 44(3): 377-381.

6. Saranya P, Geetha A. Antiulcer activity of Andrographis paniculata (Burm.f.) Wall. against cysteamine-induced duodenal ulcer in rats. Indian J Exp Biol. 2011; 49(7): 525-533.

7. Maleeka Begum, SF, Santhana Kumar, J and Swathi Balakrishnan, V, Antioxidant and hepatoproective effect of Andrographis paniculata against acetaminophen (paracetamol) induced hepatotoxicity in Albino rats. Int $\mathrm{J}$ Cur Res. 2011;3(12):64-68

8. Sukardiman H, Widyawaruyanti A, Sismindari, Zaini NC. ApoptosisInducing Effect of Andrographolide on TD-47 Human Breast Cancer Cell Line. African J Tradit Compliment Alternat Med.2007;4(3):345-351.

9. Akbarsha MA, Murugaian P. Aspects of the male reproductive toxicity/male antifertility property of andrographolide in albino rats: effect on the testis and the cauda epididymidal spermatozoa. Phytother Res. 2000;14(6):432-435.

10. Meenatchisundaram S, Parameswari G, Subbraj T, Suganya T, Michael A. Medicinal and Pharmacological Activities of Andrographis paniculata -Review. Ethno botanical Leaflets. 2009;13:55-58.

11. Berenblum J, Shubik P. A new quantitative approach to the study of stages of chemical carcinogenesis in the mouse skin. $\mathrm{Br} \mathrm{J}$ Cancer. 1947;1:373-391.

12. Agrawal RC, Jain R, Raja W, Ovais $M$. Anticarcinogenic Effects of Solanum lycopersicum Fruit Extract on Swiss Albino and C57 BL Mice. Asian Pac J Cancer Prev. 2009;10:379-381.

13. Schmid W. The micronucleus test. Mutation Res. 1975;31:9-15.

14. Aron CS. Sorg R, Zimmer D. The mouse bone marrow micronucleus test. Evaluationof 21 drug candidates. Mutation Res. 1989;223:129-140.

15. Agrawal RC, kumar S. Prevention of cyclophosphamide induced micronucleus formation in mouse bone marrow by indole-3 carbinol. Food Clin Toxicol. 1998;36:975-977. 
16. Mosmann T. Rapid colorimetric assay for cellular growth and survival: application to proliferation and cytotoxicity assays. J Immunol Methods. 1983;65(1-2):55-63.

17. Agrawal RC, Pandey P, Agrawa IN.Chemopreventive effects of Andrographis paniculata extract in Vivo and in Vitro models. Med One. 2016;1(4):1-6.
18. Ather M. Oxidative stress and experimental carcinogenesis. Indian J Exp Biol. 2002;40:656667.

19. Sedlak J, LindsayRH. Estimation of total protein-bound \& non protein sulfhydryl group in tissues with Eliman's reagent. Anal Biochem. 1968;25:192-205. 